\title{
Estimation of Genetic Parameters and Genetic Trends for Some Milk Traits in a Herd of Egyptian Buffaloes
}

A. S. Khattab and Mourad. K. A.

Faculty of Agriculture. Kafr EL-Sheikh, Tanta University and

Animal Production, Research, Institute. Ministry of Agriculture, Cairo, Egypt.

\begin{abstract}
A NORMAL first lactation records of 1180 Egyptian buffalo were collected from Mehallet Mousa , Ministry of Agriculture during the period from 1966 to 1987 . Data were used to estimate phenotypic and genetic parameters for 90 day milk yield ( $90 \mathrm{MY}$ ), total milk yield (TMY) and lactation period (LP). In addition, phenotypic and genetic trends of these traits were also examined.

Heritability estimates were $0.10 \pm 0.06,0.17 \pm 0.07$ and $0.13 \pm 0.06$ for 90MY, TMY and LP, respectively. All phenotypic and genetic correlations among different traits studied were positive and significant $(p<0.01)$.

Sires with at least 10 daughters were evaluated by best linear unbiased prediction (BLUP). Sire transmitting abilities ranged from 24 to $+33 \mathrm{~kg}$ for $90 \mathrm{MY}$, from - 147 to $+154 \mathrm{~kg}$ for TMY and from 20 to $+31 \mathrm{~d}$ for LP.

Estimates of annual phenotypic changes were $4.0 \pm 1.3 \mathrm{~kg}, 16.2 \pm$ $4.0 \mathrm{~kg}$ and $-5.7 \pm 1.6 \mathrm{~d}$ for 90MY, TMY and LP, respectively. All of these estimates were significant $(p<0.01)$, while the annual genetic changes for all traits studied were not significant .
\end{abstract}

Key words : Egyptian buffaloes, genetic trends, genetic parameters .

A goal of dairy cattle breeders is to increase genetic merit for milk production. To determine the effectiveness of breeding programs, genetic trends in dairy cattle population must be monitored.

The measure of genetic and environmental changes from field data have problems since many factors are confouned with both genetic and environmental changes. (Canon and Munoz , 1991). Henderson (1959) suggested a maximum likelihood method 
using repeatability of cow's production records to separate genetic and environmental effects. While, Rege (1991) used only first lactation records since the first lactations are free from selection, repeatability and age bias.

In Egypt, few studied have been carried out to estimate genetic and phenotypic trends for dairy traits in Egyptian buffaloes. Mourad (1984) used three methods to estimate genetic improvement per generation for $\mathbf{3 0 5}$ day milk yield : regression coefficients of generation means on generation numbers, doubling regression coefficients of sire generation means on sire generation numbers and regression coefficients of individual records on generation numbers. Sharaby and El Kimary (1982) estimated genetic trend for lactation period using best linear unbiased prediction (BLUP).

The objectives of this study were (1) to estimate phenotypic and genetic parameters of 90 day milk yield ( $90 \mathrm{MY}$ ), total milk yield (TMY) and lactation period (LP) and (2) to estimate phenotypic and genetic trends for these traits in a herd of Egyptian buffaloes.

\section{Material and methods}

\section{Data}

Data were obtained from a herd of Egyptian buffaloes at Mehallet Mousa Farm, Animal Production Research Institute, Ministry of Agriculture, Egypt. They comprised 1180 normal first lactation records covering the period from 1966 to 1987 . Number of sires and average of daughters per sire were 87 and 12.1 , respectively. Sires with less than 10 daughters were excluded. Abnormal records affected by diseases such as mastitis and udder troubles or disorders such as abortion were excluded. Traits studied were 90 day milk yield ( $90 \mathrm{MY}$ ), total milk yield (TMY) and lactation period (LP). The number of records and least squares means of different traits are presented in Table 1.

TABLE 1. Least squares means and their standard errors (S.E.) for traits studied*.

\begin{tabular}{lll}
\hline Traits & Mean & S.E. \\
\hline 90 day milk yield ( $90 \mathrm{MY}, \mathrm{kg})$ & 464 & 6 \\
Total milk yield ( TMY, kg) & 1309 & 24 \\
Lactation period ( LP, d) & 322 & 5 \\
& & \\
*Number of records $=1180$ & & \\
\hline
\end{tabular}

Egypt.J. Anim. Prod., 29, No.2 (1992) 
Bulls were assigned to naturally mate the female at random. Artifical insemination is only practised when there was a probability of genital disease infection. Heifers were served for the first time when they reached 24 mo or $320 \mathrm{~kg}$. Pregnancy was detected by rectal palpation 60 days after the last service. Buffalo bulls were chosen for breeding purposes at 2-3years of age. They were evaluated for body conformation and for semen characteristics. Each bull was used for breeding for about 3-7 years.

Animals were grazed on Egyptian clover, berseem, during December-May. During the rest of the year the animals were fed on concentrate mixture along with rice straw. Cows producing more than $10 \mathrm{~kg}$ a day and those that are pregnant in the last two months of pregnancy were supplemented with extra concentrate ration. Buffaloes were hand milked twice a day.

Analysis

Data were analysed using the Mixed Model Least Squares and Maximum Likelihood Computer Program of Harvey (1987). For total milk yield the model included year and month of calving as fixed effects, age at first calving (AFC) and lactation period as a covariate and sire as a random effect. For 90 day milk yield (90MY) and lactation period (LP) the model included year and month of calving as a fixed effects, AFC as a covariate and sire as a random effect.

Paternal half sib heritabilities $\left(\mathrm{h}^{2} \mathrm{~s}\right)$ were calculated as four times ratio of $\sigma^{2} \mathrm{~s}$ (sire variance components) to the sum of the $\sigma^{2} s$ and $\sigma^{2} e$ (residual variance components). Genetic and phenotypic correlation coefficients between any two traits were computed by using the formula outlined by Harvey (1987). The approximate standard errors of $h^{2} s$ and genetic correlations were computed according to Swiger et al. (1964).

Estimating of sire transmitting ability (ETA)

Sire transmitting abilites were calculated using best linear unbiased prediction (BLUP).

In matrix notation . the models above can be written as :

$$
Y=x f+Z s+w b+e
$$

Where $\mathrm{Y}$ was a vector of observations for each trait, $\mathrm{x}$ was a known fixed design matrix, $\mathrm{f}$ was an unknown vector of fixed effects representing the mean, year and month of calving, $\mathrm{Z}$ was a known design matrix, $\mathrm{S}$ was an unobservable vector of random sire effect, $\mathrm{w}$ was a vector of covariate variable (independent variable i.e., LP and or $\mathrm{AFC}$ ), b was a vector of partial regression of $\mathrm{Y}$ on $\mathrm{W}$, and $\mathrm{e}$ was an unobservable random vector of errors with mean zero and variance - covariance martix $1 \sigma^{2} e$. 
The mixed model equations (Henderson. 1973) are

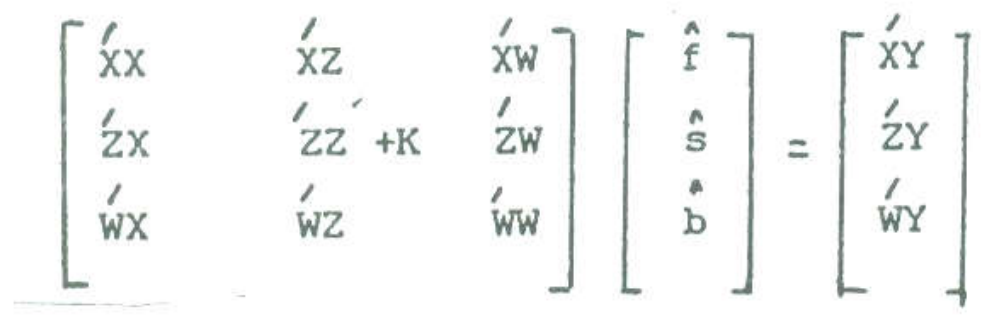

Where $k=\left(4-h^{2}\right) / h^{2}$, for each trait was added to the diagonal of sire effects in the matrix .

\section{Estimating of phenotypic and genetic trends}

The annual phenotypic change for different traits studied was computed as the regression coefficients of trait values on the year of calving after adjusting the records for season of calving , AFC and LP for TMY and season of calving and AFC for 90MY and LP.

Trends in transmitting abilities of sires for different traits studied were estimated by regressing ETA's for each year on year of calving. For the $y$ th year. $s y / r$ where $r$ is the number of daughters born in the $y$ th year.

\section{Results and Discussion}

Least squares means of different traits studied are presented in table 1 . The mean of TMY was $1309 \pm 24 \mathrm{~kg}$ produced in a lactation period (LP) $322 \pm 5$, respectively , a period recommended as the ideal period for buffaloes. EL Barbary and Badran (1986) found that the average first lactation milk yield was $1916 \mathrm{~kg}$ with LP of 328 days. The present estimate of TMY is lower than the estimate of $2241 \mathrm{~kg}$ and $2131 \mathrm{~kg}$ reported by Badran et al. (1991) and Pagnacco et al. (1992) working on Egyptian buffaloes and Italian buffaloes, respectively. Mostageer et al. (1987) reported that a lower average TMY of $1160 \mathrm{~kg}$ produced in 199 days was obtained when no animals were culled because of low production. Least squares mean of 90 day milk yield ( $90 \mathrm{MY})$ was $464 \pm$ $6 \mathrm{~kg}$. The present mean is similar to that reported by Mohamed (1986) $(416 \pm 5 \mathrm{~kg})$ using another set of Egyptian buffaloes. EL Chaife (1981) using two herds of Egyptian buffaloes calculated the average milk yield of first 100 days of lactation as 640 and 462 .

The differences between the performance found here and those reported by other workers could be attributed to one or more of the following reasons : (1) the herds were treated under different climatic and managerial conditions and or (2) different herds could possibly be genetically and phenotypically different from each cther.

Egypt.J. Anim. Prod., 29, No.2 (1992) 
Sire variance components

Sire of the heifer had a significant effect on different traits studied $(\mathrm{p}<0.05$ or $\mathrm{p}<$ 0.01 , Table 2 ) and accounting for $2.5 \%, 4.2 \%$ and $3.3 \%$ of the total variance for $90 M Y, T M Y$ and LP, respectively. Most of these findings are similar to those obtained by Badran et al. (1991) working on Egyptian buffaloes and Pagnacco et al. (1992) working on Italian buffaloes.

TABLE 2. Variance components estimates $\left(\sigma^{2}\right)$ and proportions of variation (V) due to sire effects for productive traits.

\begin{tabular}{|c|c|c|c|c|c|c|}
\hline \multirow[b]{2}{*}{ Traits } & \multicolumn{2}{|c|}{ Sire of heifers } & \multirow[b]{2}{*}{ V\% } & \multicolumn{3}{|c|}{ Remainder } \\
\hline & d.f. & $\sigma^{2} s$ & & d.f. & $\sigma^{2} e$ & V \% \\
\hline & & & $*$ & & & \\
\hline \multirow[t]{2}{*}{$90 \mathrm{MY}$} & 86 & 347 & 2.5 & 1060 & 13481 & 97.5 \\
\hline & & & $* *$ & & & \\
\hline \multirow[t]{2}{*}{ TMY } & 86 & 8533 & 4.2 & 1060 & 195139 & 95.8 \\
\hline & & & ** & & & \\
\hline LP & 86 & 344 & 3.3 & 1060 & 10234 & 96.7 \\
\hline
\end{tabular}

\section{Phenotypic and genetic parameters}

Estimates of heritability $\left(\mathrm{h}^{2} \mathrm{~s}\right)$ for productive traits and phenotypic and genetic correlations among different traits studied are given in Table 3 . Estimates of $h^{2}$ for $90 \mathrm{MY}, \mathrm{TMY}$ were $0.10 \pm 0.06$ and $0.17 \pm 0.07$ respectively. The low $\mathrm{h}^{2} \mathrm{~s}$ estimates for milk yield indicate that selection based on the phenotypic merit of the animal would not be effective. Information on the pedigree combined with the phenotypic of the individual may be used for selection of females in the initial stages, while progeny testing will be the right procedure for the selection of bulls. The present $\mathrm{h}^{2}$ estimate of TMY is nearly similar to the estimate by Pagnacco et al. (1992) working on first lactation records of ltalian buffaloes.

TABLE 3. Estimates of heritability with standard error (on diagonal), genetic correlations (below diagonal) and phenotypic correlations (above diagonal) for productive traits.

\begin{tabular}{llll}
\hline & $90 \mathrm{MY}$ & TMY & LP \\
\hline $90 \mathrm{MY}$ & $0.10 \pm 0.06$ & 0.61 & 0.25 \\
TMY & $0.62 \pm 0.24$ & $0.17 \pm 0.07$ & 0.73 \\
LP & $0.20 \pm 0.10$ & $0.97 \pm 0.10$ & $0.13 \pm 0.06$ \\
\hline
\end{tabular}


On the other hand, other investigators reported higher estimate of $\mathrm{h}^{2}$ for milk yield. Asker et al. (1965) working on Egyptian buffaloes found that $\mathrm{h}^{2}$ for $90 \mathrm{MY}$ and TMY were $0.43 \pm 0.12$ and $0.27 \pm 0.14$,respectively using daughtrers dam regression and 0.25 \pm 0.13 and $0.49 \pm 0.15$, respectively using paternal half sib methods. El Barbary and Badran (1986) using another herd of Egyptian buffaloes, found that $h^{2}$ of $70 \mathrm{MY}$ and $305 \mathrm{MY}$ were 0.24 and 0.22 , respectively . In addition, Singh and Basu (1988) found $\mathrm{h}^{2}$ for milk yield was $0.29 \pm 0.13$ on Murrah buffaloes.

Heritability estimate of LP was $0.13 \pm 0.06$ ( Table 3 ). The present estimate was in the range between 0.11 to 0.24 reported by Asker et al. (1965),Patro and Bhat (1979) and Singh and Basu (1988). The present result indicate that the major part of the variation in this character is due to nongenetic factors. In addition, great improvement in this trait could be possible by improving feeding and management system. On the other hand, higher estimate of $h^{2}$ for LP was reported by Sharaby and El Kimary (1982) working on two herds of Egyptian buffaloe being 0.32 and 0.43 .

Phenotypic correlation between 90MY and TMY was 0.61 (Table 3 ), the present estimate is in a greement with those of Asker et al. (1965), El - Barbary and Badran (1986), Jain et al. (1986) and Kassab (1988) which ranged from 0.20 to 0.86 . Our results indicate that $90 \mathrm{MY}$ could be used in evaluating the milk producing ability in buffaloes. Phenotypic correlations between LP and each of 90MY and TMY are 0.25 and 0.73 , respectively $(p<0.01$, table 3 ). The present results indicate that high productive cows were lactating for longer time.

Genetic correlation between 90MY and TMY is $0.62 \pm 0.23$ ( Table 3 ) The present estimate is similar to those of Asker et al. (1965), Jain et al. (1986), Kassab (1988) and Verma et al. (1990) which ranged between 0.76 to 0.96 . The present estimate indicate that milk yield in 90MY of lactation could be a good indicator of production in TMY. Consequently . selection for high yield of milk at 90 day of lactation will be associated with genetic improvement in the corresponding trait of TMY. Jain et al. (1986) reported that selection on the basis of part lactation may result in more genetic progress than on the basis of total milk yield. Genetic correlations between LP and each of $90 \mathrm{MY}$ and TMY were $0.20 \pm 0.10$ and $0.97 \pm 0.10$. respectively (Table 3 ) The high genetic correlation between LP and TMY indicate that selection for high milk yield bring correlated response for lactation period.

Sire transmitting ability ETA'S)

Sire values for 90MY, TMY and LP were estimated using best linear unbiased prediction (BLUP ). Number of daughters per sire ranged from 10 to 57.

Estimates of sire transmitting ablility (ETA'S) as deviation from the mean ranged from -24 to $+33 \mathrm{~kg}$ for $90 \mathrm{MY}$, from -147 to $+154 \mathrm{~kg}$ for TMY and from -20 to $+31 \mathrm{~d}$ for LP. The present results show large differences among sires in productive traits.

Egypt.J. Anim. Prod., 29, No.2 (1992) 
Similarly, EL- Chaife (1981) working on two herds of Egyptian buffaloes, found that the range of breeding values for $100 \mathrm{MY}$ and LP were large and ranged from -56 to +88 $\mathrm{kg}$ for 100MY and from - 39 to $+32 \mathrm{~d}$ for LP. Cady et al. (1983) working on 5716 lactation records of Nili Ravi buffaloes in pakistan, found that predicted sire values (BLUP) for 305 day milk yield ranged from-173 to $+260 \mathrm{~kg}$. In addition, Kassab (1988) using 1564 lactation records of Egyptian buffaloes reported that the predicted sire values for $305 \mathrm{MY}$ ranged from -297 to $+346 \mathrm{~kg}$. On the other hand, Basu and Ghai (1978) and Mohamed (1986) working on Murrah buffaloes and Egyptian buffaloes, respectively found that the expected sire breeding values did not show large genetic differences among sires.

Regarding , 90MY, TMY and LP, about $44 \%, 53 \%$ and $57 \%$ of sires had negative values, respectively . Table 4 presents proof for 90MY, TMY and LP of ten sires with the largest number of daughters in all data. Only 2 of these sires had a negative proof. The single most frequently used sire (19516) with a total of 57 daughters in the data had positive (11.2 kg, $154 \mathrm{~kg}$ and $31.2 \mathrm{~d}$ ) proof for 90MY, TMY and LP, respectively.

TABLE 4. Ten most frequently used sires and their proofs for productive traits.

\begin{tabular}{lcccc}
\hline \multirow{2}{*}{ Sire } & $\stackrel{+}{\mathbf{N}}$ & \multicolumn{3}{c}{ Proof } \\
\cline { 3 - 5 } & & $\mathbf{9 0} \mathbf{M Y}, \mathbf{k g}$ & TMY, kg & LP, d \\
\hline 15627 & 57 & 11.2 & 154 & 31.2 \\
17443 & 43 & 4.4 & 82.3 & 12.8 \\
3051 & 43 & 6.5 & 22.8 & 4.3 \\
15006 & 41 & 19.0 & 121.9 & 17.6 \\
21666 & 40 & 18.1 & 65.3 & 9.7 \\
19968 & 29 & -8.5 & -31.7 & -2.8 \\
2707 & 26 & 6.7 & 69.7 & 15.2 \\
2754 & 25 & -4.1 & -53.5 & -7.3 \\
15627 & 13 & 11.0 & 111.9 & 15.3 \\
17592 & 10 & 9.8 & 125.2 & 20.7 \\
\hline+ & & & & \\
\hline Number of half sib daughters & & & &
\end{tabular}

Egypt.J. Anim. Prod,, 29, No.2 (1992) 
Product moment correlation of EBV's between 90MY and TMY was 0.70 . The product moment correlations between LP and each of 90MY and TMY were 0.34 and 0.80 , respectively. The high product moment correlation between 90MY and TMY, indicated that sire evaluation could be possible using initial milk yield in order to minimize the time required for progeny test. This could reduce the cost of evaluation and decrease the generation interval to increase the annual genetic gain.

\section{Phenotypic and genetic trends}

Estimates of phenotypic and genetic trends for productive traits studied are given in Table 5. Annual phenotypic change for 90MY, TMY and LP were $4.0+1.3 \mathrm{~kg}, 16.2+$ $4.0 \mathrm{~kg}$ and $-5.7+1.6 \mathrm{~d}$, recpectively. All of these estimates were significant $(\mathrm{P}<0.01$, Table 5 ). The present estimates indicate that phenotypic improvement in milk production was achieved during the period of the study. The present results also indicate that the differences in performance between years are mainly due to different nutritional, climatic conditions and management practices prevalent over different times. The observed negative phenotypic change in the length of lactation period is unexpected because the same data indicated high positive phenotypic correlations between LP and each of 90MY and TMY (Table 3 ). The estimate of the negative change in LP seems to be biased down wards and this seems to be due to the data were recorded some time ago from 1966 and may have been biased by environmental effects now unknown. Therefore it could not be explained.

Similar to the present results, Mourad (1984) with first lactation of Egyptian buffaloes found positive annual phenotypic change of $6.64 \pm 1.09 \mathrm{~kg}$ and $17 \pm 3.9 \mathrm{~kg}$ for 70 and 305 day milk yield, respectively. She found negative phenotypic change for LP (- $2.9 \pm 1.1 \mathrm{~d})$. In addition, Vij and Tiwana(1986) working on Murrah buffaloes. reported that the phenotypic change for $305 \mathrm{MY}$ and LP were $72.0 \mathrm{~kg}$ and $-0.31 \mathrm{~d}$, respectively. On the other hand, negative annual phenotypic change for milk yield have been reported by Canon and Munoz (1991) $(-78 \pm 8.3 \mathrm{~kg})$ and Rege (1991) $(-5.5 \mathrm{~kg})$ working on Spanish Holstein and Kenya cows, respectively.

No specific genetic trends were observed in the productive traits (Table 5). The regression of the sire breeding values on time indicated an increase of $0.06 \pm 0.50 \mathrm{~kg}$ per year for $90 \mathrm{MY}$ and a decrease of $-1.60 \pm 1.80 \mathrm{~kg}$ for TMY and $-0.40 \pm 0.40$ for LP. All of them were not significantly different from zero (Table 5). The present results indicate that the sires used in the later years were of inferior genetic worth to those used in the earlier years. It can be inferred that the sires used in the later years did not prove to be superior sires. This may be because of ineffective selection or lack of acclimatization of the animals or both. The present estimates are in agreement with rege (1991) working on Kenya cows, found that the genetic trend per year for 305MY and first lactation milk yield were negative and not significant, being $-2.50 \mathrm{~kg} /$ year and $5.20 \mathrm{~kg} /$ year, respectively . Mourad (1984) estimated genetic trend by three methods, found that genetic trend per generation for 70MY ranged from $-1.4 \pm 4.9 \mathrm{~kg}$ to $+5.6+$

Egypt.J. Anim. Prod., 29, No.2 (1992) 
$5.3 \mathrm{~kg}$, for $305 \mathrm{MY}$ ranged from $-4.1 \pm 20.5 \mathrm{~kg}$ to $+11.8 \pm 7.7 \mathrm{~kg}$ and for $\mathrm{LP}$ ranged from $-2.0 \pm 5.9$ to $+6.0 \pm 3.3 \mathrm{~d}$. In addition, Powell et al $(1977)$ found strong negative genetic trend in two regions in the United States from 1961 to 1970 with an average sire breeding values for milk (kg.) dropping from 100 to $-220 \mathrm{~kg}$ from 1961 to 1964 in the West region and from 25 to $-150 \mathrm{~kg}$ during the same period of the time in the Midwest region .

TABLE 5. Summary of phenotypic (P) and genetic trends (EBV) in 90 day milk yield (90 MY), total milk yield (TMY), and lactation period (LP).

\begin{tabular}{|c|c|c|c|c|c|c|c|}
\hline \multirow{2}{*}{ Year } & \multicolumn{2}{|c|}{$90 \mathrm{MY}, \mathrm{kg}$} & & \multicolumn{2}{|c|}{ TMY, kg } & \multicolumn{2}{|c|}{ LP,d } \\
\hline & P & EBV & & $\mathbf{P}$ & EBV & $\mathbf{P}$ & EBV \\
\hline 1966 & 498 & 18.5 & & 1250 & 105.6 & 323 & 7.0 \\
\hline 1967 & 424 & 4.6 & & 1190 & 36.4 & 468 & 6.4 \\
\hline 1968 & 472 & -24.7 & & 1234 & -181.4 & 380 & -16.1 \\
\hline 1969 & 411 & -1.1 & & 1188 & 13.2 & 322 & 0.8 \\
\hline 1970 & 397 & -5.5 & & 1044 & 20.9 & 330 & 1.0 \\
\hline 1971 & 377 & 0.3 & & 1105 & 34.4 & 367 & 1.5 \\
\hline 1972 & 437 & -0.8 & & 1213 & 17.2 & 360 & 17.6 \\
\hline 1973 & 443 & -0.3 & & 1302 & 26.4 & 359 & 3.2 \\
\hline 1974 & 438 & 2.1 & & 1186 & 30.1 & 311 & 2.6 \\
\hline 1975 & 444 & -3.3 & & 1250 & 39.9 & 302 & 8.3 \\
\hline 1976 & 444 & 4.8 & & 1157 & 28.6 & 291 & 1.1 \\
\hline 1977 & 497 & 5.4 & & 1389 & 34.0 & 303 & -1.0 \\
\hline 1978 & 472 & 1.5 & & 1507 & 16.6 & 349 & -1.38 \\
\hline 1979 & 419 & 5.9 & & 1154 & 57.6 & 288 & 0.58 \\
\hline 1980 & 548 & 6.7 & & 1396 & 46.9 & 368 & -2.18 \\
\hline 1981 & 529 & 2.2 & & 1415 & 34.0 & 319 & -2.66 \\
\hline 1982 & 452 & 2.5 & & 1396 & 04.7 & 365 & 1.30 \\
\hline 1983 & 459 & 12.9 & & 1302 & 01.8 & 296 & -0.46 \\
\hline 1984 & 509 & -8.2 & & 1312 & -34.6 & 256 & -0.16 \\
\hline 1985 & 516 & -1.7 & & 1301 & -56.9 & 261 & -1.12 \\
\hline 1986 & 543 & -3.3 & & 1466 & -36.6 & 220 & -0.80 \\
\hline 1987 & 470 & -3.1 & & 1753 & -21.4 & 239 & -1.10 \\
\hline+ & 4.0 & 0.06 & & 16.2 & -1.6 & -5.7 & -0.4 \\
\hline b & $\begin{array}{c}++ \\
(1.3)\end{array}$ & $(0.50)$ & & $(4.0)$ & (1.8) & (1.6) & (0.4) \\
\hline $\begin{array}{l}+ \\
b=a n r \\
\text { or gene }\end{array}$ & 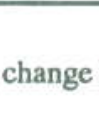 & 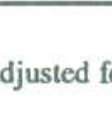 & & 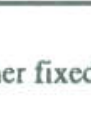 & ffects ) & & \\
\hline
\end{tabular}

Egypt.J. Anim. Prod., 29, No.2 (1992) 
On the other hand, Positive genetic trend have been reported for milk yield and LP (Sharaby and EL kimary , 1982; Weller et al. 1986 ; and Vij and Tiwana , 1986) ranging from $4.5 \mathrm{~kg} /$ year (Vij and Tiwana, 1986 ) to $102 \mathrm{~kg} /$ year (Weller et al., 1986 ). Sharaby and El Kimary (1982) working in two herds of Egyptian buffaloes, found that the expected genetic change for LP were 22 and $8 \mathrm{~d} /$ year.

Given these results, some efforts must be made to monitor genetic trends in Egyptian buffaloes and check the effectiveness of breeding programs using all available information.

\section{References}

Asker, A.A., Bedeir , L. H. and EL Itriby , A.A. (1965) The inheritance and relationships between some dairy characters in the Egyptian buffaloes. J. Anim. Prod. U.A.R. 5 : 119.

Badran, A.E., Mandour, M.A. and kassab, M.S. (1991) Reproductive performance and its relation to productive traits in Egyptian buffaloes. J. Agric. Res. Tanta University. $17: 27$.

Basu. S. B. and Ghai, A. (1978) Studies on milk production in Murrah buffaloes. Indian, J. Anim. Sci. $48: 593$.

Cady, R. A., Shah, S. K.,Schermerhorn, E. C. and McDowell, R.E. (1983) Factors affecting performance of Nili - Ravi Buffaloes in Pakistan J. Dairy Sci. 66 : 578.

Canon, J. and Munoz. H. (1991) Genetic trends for milk production in the Spanish Holstein population. J. Anim. Breed. Genet. 108 : 41.

EL Barbary, A. S. A. and Badran., A. E. (1986) Studies on buffaloes and cows in Egypt. XIII . Some production traits in Egyptian buffaloes. Alex. J. Agric. Res. 31 : 135.

EL - Chaife, O. M. (1981) Studies on cattle (cows and buffaloes) sire evaluation and genetic parameters of partial lactations, dry period and service period. M. Sc. Thesis, Faculty of Agric. Alex. University, Egypt.

Harvey, W. R. (1987)Mixed Model Least squares and Maximum Liklihood Computer Program PC 1. Ohio State University. Columbus. USA (Memeograph)

Henderson, C. R. (1973) Sire evaluation and genetic trend. Proceeding of the Animal Breeding and Genetics Symposium in honor of Dr. Jay. L. Lush. ASAS and ADSA, Champaign, p - 10

Henderson, C.R. ; Kemthorne, O.; Searle, S. R.; Von Krosick, C.M. (1959) The estimation of environmental and genetic trends from records subject to culling. Biometrics. 15: 192.

Jain, A. K., Phillon, J.S. and Parman, O.S. (1986) Genetic studies on part and complete first lactation milk yield. Indian. J. Dairy Sci. $39: 297$.

Egypt.J. Anim. Prod., 29, No.2 (1992) 
Kassab, M. S. (1988) Studies on milk production in Egyptian buffaloes. Ph. D. Thesis, Faculty of Agric., Tanta University , Egypt.

Mohamed, M. M. (1986) Sire evaluation for Egyptian Water buffaloes. Ph. D. Thesis, Faculty of Agriculture; Cairo university, Egypt.

Mourad, K. A. (1984) Genetic improvement in a herd of Egyptian buffaloes Ph. D. Thesis, Faculty of Agric. Moshtoher, Zagazig University Egypt.

Mostageer, A., Morsy, M. A., Nigm, A.A. and Sadak, R.R. (1987) The performance of some European cattle breeds in adverce environment. J. Anim. Breed. Genet. 104 : 206

Pagnacco, G., Bagnata, A., Moioli, B.M. and Pilla, A.M. (1992) Heritability and genetic correlations for milk, fat and protein in buffaloes with mulit- trait sire model . International Symposium on Prospects of Buffalo Production in the Mediterranean / Middle East Cairo, Egypt. 9 - 12 November, 1992.

Patro, B.N. and Bhat, P. N. (1979) The inheritance of production traits in buffaloes. Indian. J. Anim. Sci., $49: 10$.

Powell, R. L., Norman, H. D. and Dickinson, F. N. (1977) Trends in breeding values and production.J. Dairy Sci, $60: 1316$.

Rege, J. E. O. (1991) Genetic analysis of reproductive and productive performance of Friesian Cattle in Kenya. J. Anim. Breed. Genet. $108: 427$.

Sharaby, M. A. and EL - Kimary, I. S. (1982) Sire evaluation and genetic parameters of first lactation length in Egyptian buffaloes and high grads of Friesian cows. Alex. J. Agric. Res 30: 99.

Singh, D. and Basu, S. B. (1988) genetic parameters of first lactation traits in Murrah buffaloes. Indian Veterinary J. $65: 593$.

Swiger, L. A., Harvey, W. R., Everson, D. O. and Gorgory, K. E. (1964) The Variance of intraclass correlation involving groups with one observation. Biometrics. $20: 818$.

Verma, K., Yadav, M. C. and Jain, V. K. (1990) Genetic studies on part and complete lactation milk yield in Nil buffaloes. Indian . J. Dairy Sci . 24 : 23.

Vij, P. K. and Tiwana, M.S. (1986) Phenotypic and genetic trends in some economic traits in buffaloes. Indian. J. Anim. Sci. 54 : 328.

Weller, J.I., Ron, M. and Bar-Anan, S. (1986) Multlaction genetic analysis of the Isreali Dairy Cattle. 3 rd world Congress on genetic applied Livestock Production, July, 6-23, 1986. 


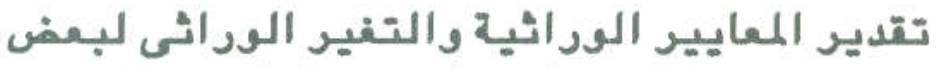

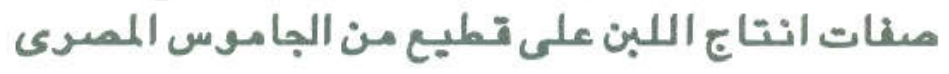

$$
\begin{aligned}
& \text { عادل صلاح خطاب ،كوثر عبد المنسم مراد } \\
& \text { كلية الزراعة بكفر الشيخ جامعة طنطل ، معهد بحوث الانتاج }
\end{aligned}
$$

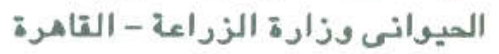

$$
\begin{aligned}
& \text { استخدام .IIA سجلا لموسم الحليب الاول لقطيع الجاموس المصرى } \\
& \text { بعطة مصلة موسى التابعة لمعهد بحوث الانتاج الميوانى بالقاهرة } \\
& \text { فى الفترة من } 17 \text { AV : بهدف دراسة المقايير المطهرية والوراثية }
\end{aligned}
$$

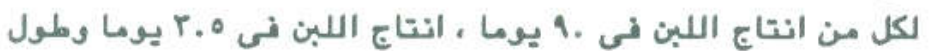

$$
\begin{aligned}
& \text { موسم المليب كذلل بغرض تقدير التغير الوراثى لهذه المغات . }
\end{aligned}
$$

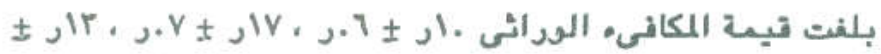

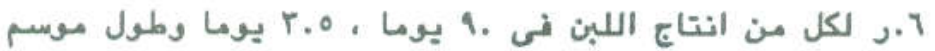

$$
\begin{aligned}
& \text { المليب على التوالى ، كانت جميع معاملات الارتباطات النهرية }
\end{aligned}
$$

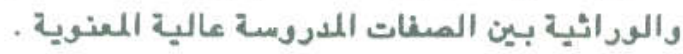

تدرت القيمة التربوية بالاباء التى لها عشرة أبناء فكثر

بطريقة أفضل انمدار خطى غير منحدر تراوحت تيم المقدرة

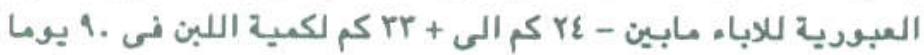

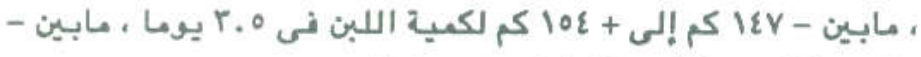

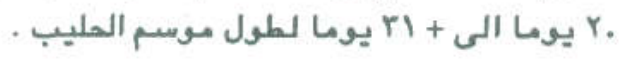

بلغ التفير المظهرى السنوى ع ع $1{ }^{2}$

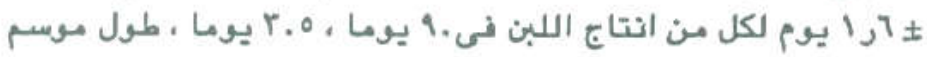
الحليب على التوالى كانت جميع التيم معنوية بينعا كانت تيم

$$
\text { التغير الوراثى السنوى للمفات الثلاث غير سعنىى . }
$$

